\title{
Effect of Gibberellic Acid Application on the Growth, Vigour, Flowering, Fruiting and Quality of Strawberry: A Review
}

\author{
Aditee Sharma* and Ankush Godara \\ School of Agriculture, Lovely Professional University, Punjab, India \\ *Corresponding author
}

\section{A B S T R A C T}

\section{Keywords}

Gibberellic acid, Strawberry, Quality, Yield, Growth

Article Info

Accepted:

26 September 2020 Available Online: 10 October 2020
Strawberry is a very unique berry fruit. It is mainly cultivated in subtropical and temperate area. Strawberry is a non climacteric fruit. It is rich in vitamin c and iron. It is lawgrowing herbaceous plant which arise basal leaves. PGR play a key role in yield and size of the fruit. $\mathrm{GA}_{3}$ has stimulate the effect on the fruit of strawberry ripening, testimonial by a reduce the activity of respiration and detain the synthesis of anthocyanin and breakdown of chlorophyll gibberellic acid influence the growth, and fruiting etc. Gibberellic acid is a growth promoting hormone which is mainly found in fungi and plants. It involves overcoming dormancy in seed and buds. Gibberellins translocates easily in the plant in both direction. It is used commercially in increasing fruit size, stimulating seed germination and seed growth.

\section{Introduction}

Strawberry is a delightful, delicious and healthy fruit. Strawberry fruit has individual and good aroma. They are very sweet flavor. It has cultivated in the very unique place. It is a manmade hybrid. Strawberry botanically known as Fragaria x ananasa Duch. Belongs to Rosaceae family with octaploid chromosome no 56(2n=8x) and Order Rosales. it is originated from France (Nathewet et al., 2010). It is fast growing crop and also it is short day plant crop. It is suitable for kitchen garden. Rich in vitamin - C and Iron (Morgan, 2005). It is an vital flavor due to Ethyl butanoate and Ethyl hexanoate. Strawberry is a good source of folic acid.
Cultivation of strawberry in the region of HP, UP, Maharashtra, West Bengal, Haryana, Punjab and Rajasthan. They have also grown in the subtropical area of $\mathbf{J} \$ \mathrm{k}$. They are grown in the region of Himalaya. In India they are exported in 400-500 tonn. The total cultivated area is 0.21 ' 000 ha. 1.61 ' $000 \mathrm{MT}$ is a total production area in the year 2013-2014 (NHB 2014).In world, strawberry cover 9.2 lakh hectare area (73 countries) and annual production of strawberry is estimate 45.9 lakh hectare.

A growth regulator, plant growth regulator is natural or synthetic chemical that influence the growth and development. Plant hormone is natural substance that act to control plant 
activities chemical messenger in a one part of plant and the transported to the other parts, where they initiated the response. They have five type of plant growth regulators: Auxins, Gibberellins, Cytokinins, Ethylene, Abscisic acid. Effect of PGRs has been investigated extensively in strawberry. They control the plant growth or increase the strawberry yield, reported by (Dwivedi et al., 1999).

Gibberellic acid have a regulatory function are produce the shoot apex primary in the leaf primodial and root system stimulates stem growth dramatically and also stimulates cell division, cell elongation and enzyme secretion. It involves over-coming dormancy in seed and buds. Gibberellins translocates easily in the plant in both direction. It is used commercially in increasing fruit size, stimulating seed germination and seed growth (Kumar et al., 2012).

Gibberellic acid is a growth promoting hormone which is mainly found in fungi and plants. It can be commercially synthesized using microorganisms. GA promotes growth endogenously and has direct effect on cell elongation, fruit set, germination, flowering and fruit development. In this review major work done on studying the effects of gibberellic acid on the growth and development of strawberry is listed. The some researchers evaluated the effect of gibberellic acid at varied concentrations individually and with addition to other growth promoters and evaluated various parameters such as flowering, fruiting, yield, quality of strawberry and the work of these researchers are discussed in this review (Khunte et al., (2014)).

\section{Effect of gibberellic acid in strawberry flowering and yield}

The impact of $\mathrm{GA}_{3}$ application in different concentrations $(0,5,10,15 \mathrm{ppm})$ on strawberry cv. Camarosa at second and fourth week of January. The GA3 was applied exogenously on the strawberry plant. The study revealed that the application of gibberellic acid resulted in early flowering without reduction in yield and quality of fruit. The results were best seen at $10 \mathrm{ppm}$ concentration of GA3 exceed the elongation axillary shoot and decrease formation of callus. Specifically, it was observed that under low concentration of $\mathrm{GA}_{3}(1.0,2.0 \mathrm{mg} \mathrm{d} / \mathrm{m} 3)$ axillary shoots (mainly crown shoots) were elongated and under high concentration of GA $(5.0,10.0 \mathrm{mg}$ $\mathrm{d} / \mathrm{m} 3$ ) there was stimulation in development of runners (Ahsen et al., (2002)). A study was conducted Rzeszow University, Poland where they developed in vitro shoot cultures of strawberry under the influence of higher doses of gibberellic acid and growth and development of strawberry was evaluated. The doses of GA were 1.0, 2.0, 5.0, $10.0 \mathrm{mg}$ $\mathrm{d} / \mathrm{m} 3$. It was generally observed by (Wojciech et al., 2009).

The effects of gibberellic acid and chilling treatment on the vegetative growth and vigour of strawberry plants. Elsanta cultivar of strawberry was used in the research and plants for chilling treatment were kept in polybags in cold storage room at 3 degree Celsius at 2, 4, 6,8 and 10 week and observation were recorded. To compare whether GA can mimic the effects of chilling treatment, another batch of plantlets were sprayed with GA at varied concentrations. It was observed that gibberellic acid increases the vegetative growth but simultaneously the length of inflorescence and therefore the shape of fruit become abnormal. Also, at $50 \mathrm{ppm}$ concentration of GA the abnormalities were least. This research is conducted by (Tehranifar and Battey, 1997).

The spray of gibberellic acid $\mathrm{GA}_{3} @ 75$ ppmhas decrease the weight of strawberry berry and also affect on the fruit set, but 
increase the total yield and total number of fruit and there hi no wrong impact on the quality parameter of fruit and also number of yield was increase tis is observed by (Sharma and Singh 2009). Singh and Singh (2009) is confirm that the cultivar of strawberry treated with gibberellic acid and chemical fertilizer $\mathrm{GA}_{3} @ 100$ ppm. The Application of $\mathrm{GA}_{3}$ mixed with auxin and increases the yield of strawberry variety Camarosa (Roussos et al., 2009). However, the Application of $\mathrm{GA}_{3} @ 75$ ppm the number of flower and fruit yield is increased therefore it is confirm by the (Uddin et al., (2012).

\section{Effect of $\mathrm{GA}_{3}$ on growth and yield of strawberry}

It has been reported that the Application of $\mathrm{GA}_{3}$ has influence on the plant growth model, that stimulate good plant length height, leaf length which is harmonize with cell elongation intercalary meristem that is further associated with cell division (Sauter and Kende, 1992). The cell growth is not modulate with the gibberellins that stimulate with auxin synthesis verify by the Ockerse and Galston (1967).

It was observed that there is stem elongation induced by gibberellin which include the early expansion with different kinetic which is followed by long and mid term expansion due to enhancing the action of IAA, but increase in endogenous level of auxin was not seen. Many authors are considered that the $\mathrm{GA}_{3}$ work as a growth promoter and also explain that the impact of abundant concentration of $\mathrm{GA}_{3}$ on various growth parameter such as plant height, leaf length, shape of leaf, bunch of plant and production of runner etc, (Barralt and Davies (1977)). The applied over the 2 week of flowering the application of GA4 +7 at $15 \mathrm{ppm}$ and Promalin $(1.8 \%$ of GA4 +7 and $1.8 \%$ of $6-$ Benzyladenine) @ 6ppm for growth of plant and area of leaf under protected cultivation of strawberry cultivar. This is recommended by (Thakur et al., 2017).

The4 concentration of GA3 i.e.@50, 100, 150 and $200 \mathrm{ppm}$ at the stage of 4 leaf and the subsequent time of a week then notice that the extend the length of petiole and their is no effect on the size and number of leaf an $d$ the branches of plant and reduce the production of fruit(Luangprasert (1994)). The gibberellin effect on the growth of vegetative part of the strawberry and also promote the growth of the strawberry. Concentration of $\mathrm{GA}_{3} @ 80 \mathrm{ppm}$ ) is good for the vegetative growth and runner production of strawberry is confirmed by (Rajesh et al., 2012). The growth of runner production is increase and it is also related with inhibitory effect on flowering also stimulates the expansion of parenchymatous and epidermal cell reported by Akath and Singh (2009).

It has been reported that the reaction of chemical fertilizer or nitrogen fixing bacteria combination with plant bio-regulators on strawberry cultivar. The application of $\mathrm{GA}_{3}$ (100ppm) has been observed that increase the height of plant, shape of leaf, number of leaf and area of leaf. Application of $\mathrm{GA}_{3}$ applied with the mixing Azotobacter and Azospirillium during the $60 \mathrm{~kg}$ N/ha conducted by ingh and Singh (2009). The application of the $\mathrm{GA}_{3}$ the $(75 \mathrm{ppm})$ to increase the plant height, number of leaves and area of leaf in strawberry plant conducted by Uddin et al., (2012).

The strawberry cultivar vigrous runner production in the specific year. some runner plants are treated with the application of $\mathrm{GA}_{3}$ and keep it under the cold temperature for 25 days s. The application of the concentration of $(\mathrm{GA} 4+7$ at $15 \mathrm{ppm})$ or Promalin (GA4+7 (1.8\%) or 6-Benzyladenine (1.8\%) @ 6ppm to increase the height and growth of plant it is 
confirm by (Thakur et al., (2017)). In strawberry cultivar to applied the application $\mathrm{GA}_{3}$ (25, 50,75ppm), cycocel @ 300, 600, 900ppm) or triacotanol @ 1.25, 2.5, 5ppm) observed that the yield of strawberry fruit is maximum i.e. $(376.69 \mathrm{~g} / \mathrm{plant})$ and number of fruit is also increase i.e. (23.31) 1:50 length: diameter ratio of fruit was observed with the concentration of 5ppm triacotanol confirm by Sangwook et al., (1996).

It has been reported that there is an increase in number of fruits per plants by the application of gibberellic acid $\left(\mathrm{GA}_{3}\right) @ 50 \mathrm{ppm}$ in Camarosa cultivar of strawberry. (ALMadhagin et al., (2012)). similarly that maximum number of flowers (28.7/plant) maximum yield (25.9/plant) and maximum number of fruits where seen in strawberry plants which where treated with $\mathrm{GA}_{3} 75$ ppm followed by $\mathrm{GA}_{3} 100 \mathrm{ppm}$ and least (21.1,248.9gm /plant, 19.6/plant respectively) in control reported by (Uddin et al., 2012).

\section{Effect of gibberlic acid in strawberry fruit ripening}

The effect of gibberellic acid on post-harvest ripening of strawberry by evaluating various biochemical parameters like anthocyanin content and chlorophyll content. The strawberry plants at different growth stages were harvested and incubated with gibberellic acid. The observations indicated that gibberellic acid had an inhibitory effect on strawberry respiration and thus reducing the ripening. Also, GA3 accounted for chlorophyll degradation and delay in the synthesis of anthocyanin due to inhibition in respiratory function (Martinez et al., 1994).

\section{Effect of gibberellic acid $\left(\mathrm{GA}_{3}\right)$ on quality of strawberry fruit}

$\mathrm{GA}_{3}$ 100ppm + vermicompost @ 100q/ha resulted more TSS (10.68 ${ }^{\circ}$ Brix) in strawberry var. Douglas. It was observed that the increase the number of fruit and also increase the juice content i.e $87.37 \%$ with the application of gibberellic acid $\left(\mathrm{GA}_{3}\right)$ @ 30ppm and also the application of gibberellic acid $\left(\mathrm{GA}_{3}\right)$ @ 90ppm the increase the ascorbic acid 64.04 and acidity also increased (Rajbhar et al., 2015).

The variety sweet Charlie in strawberry in various type of plant growth regulator are effected on the different concentration of gibberellic acid $\left(\mathrm{GA}_{3}\right) @ 25$ and $75 \mathrm{ppm}$, cycocel 300 and $600 \mathrm{ppm}$ and that is also resulted that the specific gravity and ph in higher range at the application of tryptophan and the application of Cycocel @ 900ppm shows that the rich in vitamin content and the sugar level is also increase (Kumar et al., (2012) i.e. $9.63^{\circ}$ brix and it also increase the content of juice) gives highest vitamin $\mathrm{C}$ $(55 \mathrm{mg} / 100 \mathrm{gm})$, total sugar $(9.40 \%)$, TS (9.40\%), TSS (9.63degree Brix), juice content and level of ascorbic acid in the chandler variety of straw berry . the spray of the application of $\mathrm{GA}_{3} @ 75 \mathrm{ppm}$ twice in the month of mid November to the mid of February, this is considered that the Roussos et al., (2009).

In conclusion the application of gibberellic acid applied the plant in different concentration. it influence the growth of strawberry. Gibberellic acid had different effect on respiration and thus reduce the ripening. The effect of different concentration of gibberellic acid $\mathrm{GA}_{3}$ various parameter of growth like height of plant, leaf length, fruit size etc. application of GA3 resulted early flowering concentration of 10ppm should be applied three times at weekly intervals starting in the autumn, when the flowers are first initiated (Smith et al., 1961), fruit is also in good textured (Smith et al., 1961). It enhances the cell elongation. 


\section{References}

Ahsen I. Ozgüven and Cenap Yilmaz, (2002). The Effect of Gibberellic Acid Treatments on the Yield and Fruit Quality of Strawberry (Fragaria $\times$ ananassa) $\mathrm{Cv}$. Camarosa. Proc. 4th Int. Strawberry Symp. Eds. T. Hietaranta et al. Acta Hort. 567, ISHS.

Akath S, Singh JN(2009). Effect of bio fertilizers and bio regulators on growth and nutrient status of strawberry $\mathrm{Cv}$. Ali M, Toktam ST, Shokofeh M.

Al-Madhagi Isam Abdulbaset Haidar, $\mathrm{H}$. Ahmad Aziz bin, Zain Abdullah $\mathrm{M}$ and Yusoff Wan Abdullah bin( 2012). The influence of exogenous hormone on the flowering and fruiting of strawberry (Fragaria $\mathrm{x}$ ananassa Duch.). Journal of Biology, Agriculture and Healthcare, 2(4), 46-52.

Barratt S, Singh JN(2002) Effect of bio fertilizers and bio regulators on growth and nutrient status of strawberry $\mathrm{Cv}$. Ali M, Toktam ST, Shokofeh M.

Barrattey NM, Davies PJ( 1997); Developmental changes in the gibberellininduced growth response in stem segments of light-grown pea genotypes. Plant growth regulation 21(2):127-134.

Kahangi E. M., Y. Fujime and E. Nakamura,( 1992). Effects of chilling and growth regulators on runner production of three strawberry cultivars under tropical conditions. Journal of Horticultural Science 67 (3) 381-384.

Khunte S. D., Kumar A., Kumar V., Singh S. and Saravanan S.( 2014). Effect of plant growth regulators and organic manure on physico-chemical properties of strawberry (Fragaria $\mathrm{x}$ ananassa Duch.) cv. Chandler. International Journal of Scientific Research and Education, 2(7): 158-165.

Kumar R., Bakshi M. and Singh B.D. (2012b). Influence of plant growth regulator on growth, yield and quality of strawberry (Fragaria $\mathrm{x}$ ananassa Duch.) Under U.P. Subtropics, the Asian journal of
Horticulture, 7(2):434-436.

Kumar R., Bakshi P., Srivastava J.N. and Sravanan S.( 2012a). Influence of plant growth regulators on growth, yield and quality of strawberry (Fragaria $x$ ananassa Duch.) cv. Sweet Charlie. The Asian Journal of Horticulture, 7(1): 40- 43.

Kumar, R., Sharma, N., Jamwal, M., Sharma, R. M., Singh, D. B., and Parmar, A. M. (2012). Production and economic studies of PBRs treated strawberry (Frageria $\mathrm{x}$ ananassa Duch.) cv. Sweet Charlie. American-Eurasian Journal of Agriculture and Environmental Science, 12(12), 1.

Luangprasert N(1994). Effect of gibberellic acid on growth and fruit production of Tioga strawberry grown in winter on highland of phetchaboon province. Acta Horticulture ; (28):22-26

Martinezg.G.A., A. R. Chaves, and M. C. Afion,(1994). Effect of Gibberellic Acid on Ripening of Strawberry Fruits (Fragaria annanassa Duch.). J Plant Growth Regul 13:87-91.

Mohammad A, Hafiz I, Abdul H(1990). Effect of different concentrations of gibberellic acid on the growth and yield of strawberry. Sarhad J. Agric. ; 6(1):57-59

NHB (2014)Statistical database national horticulture board , Gurgaon , http://nhb.gov.in/area_producton.html

Paroussi G., D.G. Voyiatzis, E. Paroussis, P.D. Drogoudi(,2002). Effect of GA3 and Photoperiod Regime on Growth and Flowering in Strawberry. Proc. 4th Int. Strawberry Symp. Eds. T. Hietaranta et al. Acta Hort. 567, ISHS 2002

Rajbhar Y.P. Singh B. Singh G. Singh D.K and Kumar M.( 2015). Studies on the effect of growth regulator and vermicompost on growth and yield of different cultivers of strawberry (Fragaria x ananassa Duch). The Asian Journal of Horticulture, 10(2): 222-23

Sangwook RA, Kimwoonse, Su Jin Y, Nsik W, Chansik M, (1996). Effects of cold storage, GA3, photoperiod and lower cluster removal on runner development in mother plant of ever bearing strawberry. J. 
Agric. Sci. Hort. ; 38(1):616-620

Sauter M, Kende H. (1992). Gibberellininduced growth and regulation of the cell division cycle in deep water rice. Plant; 188(3):362-368.

Sharma R.R, R. Singh, (2008). Gibberellic acid influences the production of malformed and button berries, and fruit yield and quality in strawberry (Fragaria ananassa Duch.). Scientia Horticulturae 119 (2009) 430-433 .

Sharma RR, Singh R (2009). GA3 influences incidence of fruit malformation, berry yield and fruit quality in strawberry (Fragaria $\mathrm{x}$ ananassa Duch.). Acta Horticulturae 2009; 842:737-740

Singh A, Singh JN,2009. Effect of bioregulators on growth, yield and nutrient status of strawberry cv. Sweet Charlie. Indian Journal of Horticulture; 66(2):220-224

Singh V. K. and Tripathi V. K.( 2010). Efficacy of GA3, boric acid and zinc sulphate on growth, flowering, yield and quality of strawberry cv. Chandler. Progressive Agriculture, 10(2): 345-348.

Singh, A. and Singh, J.N. (2009). Effect of bioregulators on growth, yield and nutrient status of strawberry cv. Sweet Charlie. Indian Journal of Horticulture, 66(2): 220224
Smith CR, Soczek Z, Collins WB(1961). Flowering and fruiting of strawberries in relation to gibberellins. Advance

Tehranifar and N.H. Battey, 91997). Comparison of the effects of GA3 and chilling on the vegetative vigour and fruit set in strawberry. Proc. Third Int. Strawberry Symp. Eds. H.A. Th. Van der Scheer, F. Lieten, J. Dijkstra Acta Hort. 439 Vol 2 ISHS

Thakur S, Mehta K, Sekhar RS,(2015). Effect of GA3 and Plant Growth Promoting Rhizobacteria on growth, yield and fruit quality of strawberry (Fragaria $\times$ ananassa Duch.) cv Chandler International Journal of Advanced Research; 3(11):312-317.

Uddin, A. J., Hossan, M. J., Islam, M. S., Ahsan, M. K. and Mehraj, H.( 2012). Strawberry growth and yield responses to gibberellic acid concentrations. J. Expt. Biosci, 3, 51-56

Wojciech Litwinczuk, Ewa Okolotkiewicz, Iwona Matyaszek, (2009). Development of in vitro shoot cultures of strawberry (Fragaria $\times$ ananassa Duch.) 'Senga Sengana' and 'Elsanta' under the influence of high doses of gibberellic acid. Flori. horticulture FAnn. 21/2, 2009, 43-52.

\section{How to cite this article:}

Aditee Sharma and Ankush Godara. 2020. Effect of Gibberellic Acid Application on the Growth, Vigour, Flowering, Fruiting and Quality of Strawberry: A Review. Int.J.Curr.Microbiol.App.Sci. 9(10): 3426-3431. doi: https://doi.org/10.20546/ijcmas.2020.910.395 